\title{
Treatment of wastewater from biodiesel plants using microbiological reactor technology
}

\author{
Y. Khan $\cdot$ R. Yamsaengsung $\cdot$ P. Chetpattananondh $\cdot$ \\ W. Khongnakorn
}

Received: 28 September 2013/Revised: 10 December 2013/Accepted: 11 January 2014/Published online: 29 January 2014

(C) Islamic Azad University (IAU) 2014

\begin{abstract}
The objective of this paper was to introduce the aerobic microbiological reactor technology for wastewater treatment of biodiesel plants and find out the key factors that are involved in membrane fouling. The research was carried out in two steps. In the first step, sulfuric acid of $\mathrm{pH}$ 2, 2.5 and 3 was added to biodiesel wastewater and significant reduction in organic pollutants was observed at $\mathrm{pH}$ 2.5 such as chemical oxygen demand, and oil and grease were found to be 74-84 and 84.2-92.6 \%, respectively. In the second step, microbiological reactor was operated at different hydraulic retention times of $15,12,9$ and $6 \mathrm{~h}$ along with an increase in organic loading rates (range 1-3 g/L day) on individual hydraulic retention times. However, overall chemical oxygen demand and oil and grease removal efficiency remained in the range of 91.7-97.20 and 95.5-97.9\%, respectively, throughout the experiment, while severe membrane fouling was observed with decreasing hydraulic retention time due to decrease in dissolved oxygen concentration and increase in mixed liquid suspended solids, and soluble microbial product containing protein and polysaccharide. At lower hydraulic retention time of $6 \mathrm{~h}$, an increase in particle size was reported as 27.9-62.7 $\mu \mathrm{m}$, and soluble microbial product containing protein and polysaccharide reported as 20-60 and $19-59 \mathrm{mg} / \mathrm{L}$, respectively. Higher soluble microbial
\end{abstract}

Y. Khan $(\varangle) \cdot$ R. Yamsaengsung $\cdot$ P. Chetpattananondh Department of Chemical Engineering, Faculty of Engineering, Prince of Songkla University, Hat Yai 90112, Songkhla, Thailand

e-mail: yasir_engg786@hotmail.com

W. Khongnakorn

Department of Civil Engineering, Faculty of Engineering, Prince of Songkla University, Hat Yai 90112, Songkhla, Thailand product level led to increase in particle size with irregular shape, which led to severe membrane fouling.

Keywords Biodiesel wastewater treatment - Membrane fouling $\cdot$ Microfiltration $\cdot$ Oil-rich phase $\cdot$ Submerged membrane bioreactor

\section{Introduction}

Fossil fuels, such as petroleum, natural gas and coal, are limited, non-renewable energy sources, while there is a continuous increase in energy demand today. Consequently, there is an increasing urgency to search for new sustainable and renewable sources that can produce a sufficient quantity of energy with acceptable safety (environmental and human) and reliability. Biodiesel is found to be a great alternative fuel produced from the transesterification reaction of triglycerides from vegetable oils or fats with alcohols such as methanol and ethanol in the presence of a homogenous base catalyst such as $\mathrm{NaOH}$ or $\mathrm{KOH}$. Biodiesel is biodegradable and non-toxic, burns with low sulfur, carbon monoxide and aromatic-free emission profile and is environmentally beneficial in terms of recycling of spent oils and fats (Siles et al. 2011). More than $90 \%$ of the biodiesel production in Thailand uses palm oil as the raw material using transesterification reaction method. This method has a high conversion rate of oil (triglycerides) to biodiesel (methyl esters) using a simple chemical reaction that occurs in a short time (Marchetti et al. 2007). The untreated biodiesel from transesterification method contains several impurities, such as free glycerol, soap, metals, methanol, free fatty acids (FFA), catalyst, water and glycerides, which will affect the performance and durability of the diesel engine (Berrios and Skelton 2008). Therefore, the purification stage is essential. 
The more traditional purification method is wet washing, which involves using water or a weak acid to remove some of the excess contaminants and leftover production chemicals from the biodiesel. However, inclusion of additional water to the process has many disadvantages, including increased cost and production time, generation of highly polluting effluent (wastewater) that needs to be treated prior to environmental discharge, and significant loss of biodiesel in the wastewater phase (Berrios and Skelton 2008; Canakci et al. 2001). With the likely expansion of biodiesel production by plants using the conventional method (alkali-catalyzed transesterification), at least in the near future, is the inherent need to treat the wastewater. In the conventional process, for every $100 \mathrm{~L}$ biodiesel produced, some $20 \mathrm{~L}$ of raw biodiesel wastewater is discharged (Suehara et al. 2005). It was reported that the capacity of biodiesel production was approximately $1.5 \mathrm{~mL} /$ day with 43 biodiesel plants registered with the Department of Industrial Work (Department of Alternative Energy Development and Efficiency) (Chavalparit et al. 2009). It was observed that greater than $350,000 \mathrm{~L} /$ day of biodiesel production can result in 70,000 L/day of biodiesel-contaminated wastewater (Jaruwat et al. 2010). It is also found that if factories discharge wastewater exceeding the BOD limit $(500 \mathrm{mg} / \mathrm{L})$, then they have to pay around $128.45-160 \mathrm{USD} /$ $\mathrm{m}^{3}$ (Ngamlerdpokin et al. 2011).

Several processes have been developed to find out the suitable treatment procedure for managing biodiesel wastewater for both environmental and economic reasons, such as the use of microbiological process (Suehara et al. 2005; Kato et al. 2005) and anaerobic digestion (Nishiro et al. 2007). Although these processes are the most efficient and economic way to reduce the environmental impacts of biodiesel wastewater, they also generate large amounts of low-density sludge with low decomposition efficiency (Suehara et al. 2005). Chemical coagulation and electrocoagulation processes are also proposed for the treatment of wastewater from biodiesel plants (Chavalparit et al. 2009). However, the major drawbacks of the coagulation process, the requirement of a large treatment area and the contamination of chemical coagulants in the treated wastewater, remained (Ngamlerdpokin et al. 2011; Feng et al. 2004), and electrocoagulation process is possibly suitable for a primary treatment of biodiesel wastewater but it still requires a further biological treatment process (Emamjomeh et al. 2009; Calvo et al. 2003; Bolzonella et al. 2006; Chavalparit et al. 2006).

Therefore, there is a need to develop a more efficient treatment technique for the wastewater treatment of biodiesel plants. MBR has emerged as the water treatment and reclamation technology of choice among both municipal and industrial end users, but there are several associated restraints, such as cost of the system, replacement of membranes, and operation and maintenance cost (Frost and
Sullivan 2010), which inhibits the application of MBR. Recent efforts have been made to modify the MBR process to make it widely applicable in wastewater treatment and reclamation in terms of high removal efficiency and reduction in membrane fouling (Tri et al. 2002). The MBR has been identified in Europe as a key innovative technology in the report from the water issue group in preparation for the European Environmental Technologies Action Plant (ETAP). In addition, it was described in the IPPC-BREF (Best Available Technique Reference document) of the chemical sector (Frost and Sullivan 2003) and is expected to be identified as the best available technique by other industrial sectors in Europe, as many MBR units have been constructed over the last decade to treat wastewater of automotive, chemical, pharmaceutical, textile and paper mill industries, or food processing and landfills. Actually, most of the MBR plants operated in Europe service industrial companies. In France, more than 22 MBR plants designed and built by the group Veolia Water, 19 of which are implemented for industries (IPPC 2003). In 1989, the Japanese Government launched a 6-year R\&D project with many large Japanese companies, in order to develop low-cost treatment processes utilizing MBR to produce reusable water from industrial, municipal and domestic wastewater (Kimura et al. 1991).

Due to the limitation of MBR on high-grease wastewater, no research has been conducted to analyze the effect of MBR on wastewater treatment of biodiesel plants. Therefore, in the present work, it has been suggested that the combination of MBR technology with pretreatment step can increase the viability of the process and make it good alternative over the conventional wastewater treatment techniques of biodiesel plants. However, membrane fouling that leads to high energy consumption and high cleaning chemical requirement has also limited the application of the MBR process due to high operation cost (Tri et al. 2002). Therefore, the influence of HRT on membrane fouling is also analyzed in this research, and the relationship between HRT and biomass characteristics, including soluble microbial product (SMP), particle size distribution (PSD) and dissolved oxygen (DO) concentration, is studied systematically to specify how the HRT affects membrane fouling.

The whole experiment was performed from June 6, 2011, to April 13, 2013, in Prince of Songkla University, Hat Yai, Thailand.

\section{Materials and methods}

Research methodology

A schematic diagram of the microbial reactor is shown in Fig. 1. The reactor consisted of a cylindrical acrylic tank 


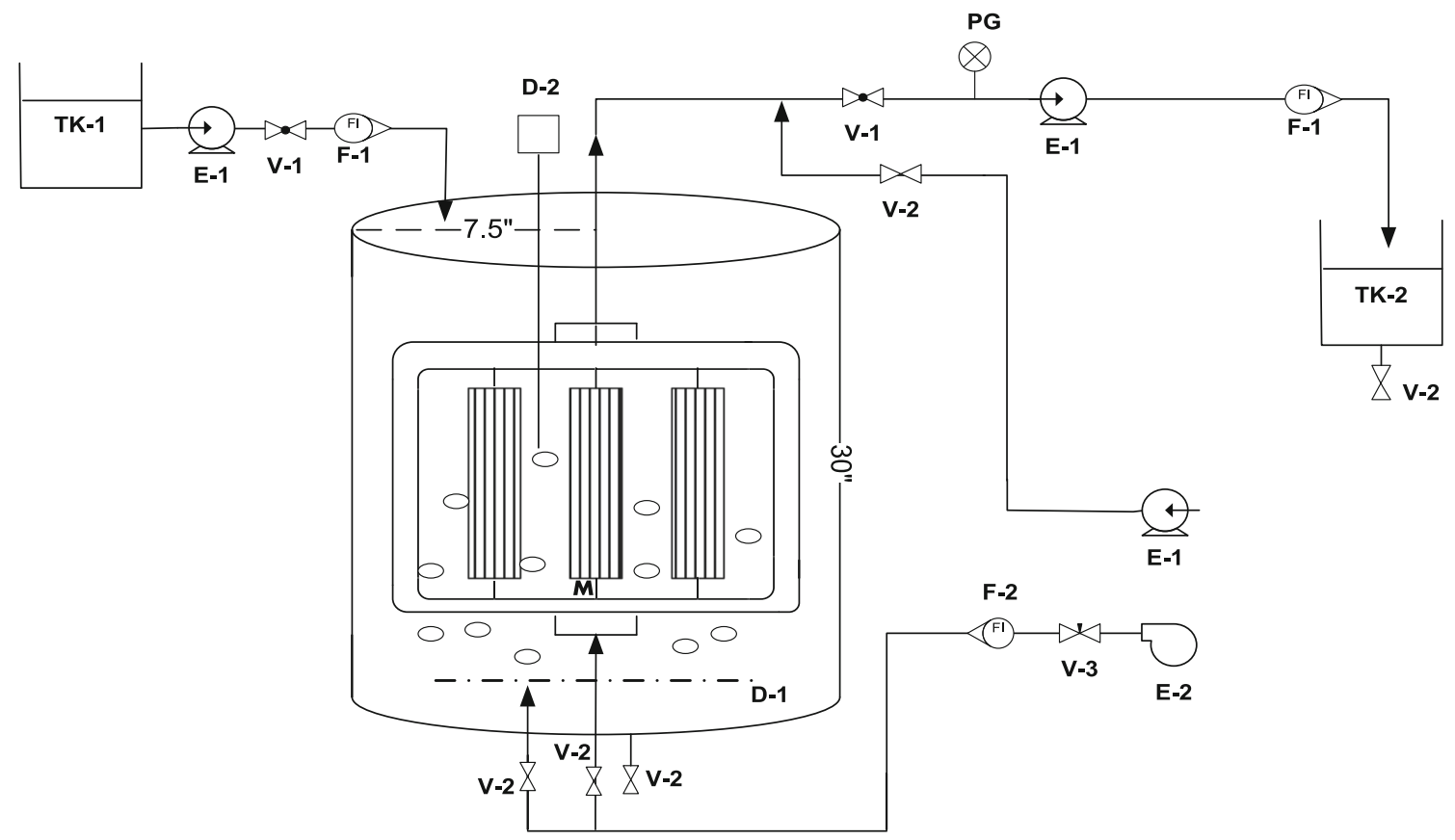

Fig. 1 Schematic diagram of the MBR: $(T K-1)$ feed tank, $(T K-2)$ effluent tank, $(E-1)$ peristaltic pump, $(E-2)$ blower, $(F-1)$ rotameter for liquid, $(F-2)$ rotameter for air, $(V-1)$ globe valve, $(V-2)$ gate valve, $(V$ -

with a working volume of $50 \mathrm{~L}$. MBR was equipped with submerged hollow fiber membrane made of PVDF (polyvinylidene fluoride) material with a nominal pore size of $0.1 \mu \mathrm{m}$ and an effective surface of $0.23 \mathrm{~m}^{2}$. Before beginning the experiment, pretreatment of biodiesel wastewater was carried out. The characteristics of biodiesel wastewater are mentioned in Table 1. Raw biodiesel wastewater was acidified by the addition of $1 \mathrm{M} \mathrm{H}_{2} \mathrm{SO}_{4}$ as a proton donor to the indicated final $\mathrm{pH}$ (range 2-3) and mixed by shaking in a separatory funnel at different retention times (range 5-15 min). After pretreatment of biodiesel wastewater with $\mathrm{H}_{2} \mathrm{SO}_{4}, \mathrm{MBR}$ operation was initiated by adjusting the OLRs from 1 to $2,3 \mathrm{~g} / \mathrm{L}$ day. COD input values to MBR were calculated on the basis of OLRs as described in "Appendix 1." The lab-scale setup comprises of the feed tank, submerged MBR and MBR effluent tank. The experiments were carried out under aerobic condition. Compressed air was supplied through diffuser aligned at the bottom of membrane at the flow rate of $14.15 \mathrm{~L} / \mathrm{min}$, providing $\mathrm{O}_{2}$ for the biological processes and simultaneously generating a cross-flow shearing effect over the membrane surfaces. Dissolved oxygen (DO) was measured by titration, which ranged from 1 to $4 \mathrm{mg} / \mathrm{L}$. The operation conditions are listed in Table 2. A pH was monitored using $\mathrm{pH}$ meter and maintained in the range of 6.00-8.00 by dosing the $1 \mathrm{M} \mathrm{H}_{2} \mathrm{SO}_{4}$ or $1 \mathrm{M} \mathrm{NaOH}$. During the utilization of membrane, no biomass was wasted from
3) needle valve, $(M)$ membrane, $(P G)$ vacuum gauge, $(D-1)$ diffuser and $(D-2)$ dipstick

reactor and solid retention time (SRT) controlled by volume of MLSS (mixed liquid suspended solids) wasted daily from reactor.

Table 1 Characteristics of raw biodiesel wastewater

\begin{tabular}{llll}
\hline Parameters & $\begin{array}{l}\text { PCD } \\
\text { standards } \\
\text { (Thai) }\end{array}$ & $\begin{array}{l}\text { EPA } \\
\text { standards }\end{array}$ & $\begin{array}{l}\text { Average values of raw } \\
\text { biodiesel wastewater }\end{array}$ \\
\hline $\mathrm{pH}$ & $5.5-9$ & $6-9$ & 10 \\
$\mathrm{COD}(\mathrm{mg} / \mathrm{L})$ & 400 & 150 & 64,625 \\
$\mathrm{BOD}(\mathrm{mg} / \mathrm{L})$ & $\leq 60$ & 130 & 34,000 \\
O\&G $(\mathrm{mg} / \mathrm{L})$ & $\leq 5$ & 10 & 20,500 \\
\hline
\end{tabular}

Table 2 Operating conditions of MBR

\begin{tabular}{ll}
\hline Parameters & Value \\
\hline Working volume of reactor (L) & 50 \\
HRT (h) & $15,12,9,6$ \\
pH & $6-8$ \\
OLR (g/L day) & $1,2,3$ \\
SRT (days) & 28 \\
Aeration intensity (L/min) & 14.15 \\
Working pressure (Kpa) & $10-30$ \\
\hline
\end{tabular}


Wastewater was fed from the feed tank to the MBR by a peristaltic pump, while constant level and hydraulic retention time (HRT) in bioreactor were maintained by discharging the membrane-filtered effluent from the reactor. Membrane-filtered effluent was intermittently discharged at a constant flux by a peristaltic pump (controlled with timer), installed at the outlet of membrane. Each intermittent cycle consisted of 8 -min suction followed by 2 -min non-suction period. Nonsuction periods facilitated back-transport of membrane foulants under pressure relaxation. During filtration, suction pressure of the effluent pump was determined by vacuum gauge positioned at the outlet of membrane, indicating the pressure difference between outside and inside of the membrane. The observed increase in or the need for a higher suction pressure to maintain a constant permeating flux gave an indirect indication of fouling. Hence, membrane cleaning was initiated once suction pressure exceeded $50 \mathrm{kPa}$.

The fouled membrane was withdrawn from the reactor, washed with tap water to remove accumulated biomass and thin layer of cake from the surface of the membrane and treated at the initial transmembrane pressure (TMP) of $10 \mathrm{kPa}$. When mechanical cleaning was unable to recover the initial transmembrane pressure (TMP) of $10 \mathrm{kPa}$, chemical cleaning was applied with $\mathrm{NaOCl}(300-500 \mathrm{mg} /$ L) to recover the initial transmembrane pressure (TMP).

\section{Analytical method}

Production of soluble microbial product (SMP) was analyzed by measuring the levels of protein and polysaccharide in bioreactor. The sample was withdrawn from the bottom of the reactor and analyzed by following the protocols of Lowery and Anthrone methods, as proposed by (Raunkjaer et al. 1994). Protein was analyzed by Lowry method, whereas polysaccharide was analyzed by Anthrone method. MLSS, COD, BOD and O\&G were measured according to analytical methods as described in standard methods (APHA 1995); dissolved oxygen (DO) concentration was analyzed by titration, while particle size was analyzed using the Mastersizer (Malvern, version 5.1).
Statistical analysis

Statistical analysis was performed using the SPSS program (version 12). Data were analyzed using one-way analysis of variance (ANOVA) to compare the effect of $\mathrm{H}_{2} \mathrm{SO}_{4}$ at $\mathrm{pH} 2,2.5$ and 3, respectively, for the removal of $\mathrm{BOD}_{5}, \mathrm{COD}$ and $\mathrm{O} \& \mathrm{G}$ in pretreatment step. To detect the statistical significance of differences $(p<0.05)$ between means of treatments, the post hoc corrected $t$ test was performed.

\section{Results and discussion}

Pretreatment of biodiesel wastewater with $\mathrm{H}_{2} \mathrm{SO}_{4}$

When $1 \mathrm{M}$ of $\mathrm{H}_{2} \mathrm{SO}_{4}$ was added directly to the raw biodiesel wastewater, the mixture was automatically separated into two phases: the lower phase was the aqueous phase having low turbidity and transparent color, whereas the upper phase was oil rich and yellow in color similar to biodiesel. For the aqueous phase, attained after protonation and extraction of raw biodiesel found that BOD, COD and oil and grease $(\mathrm{O} \& \mathrm{G})$ were significantly reduced to approximately 27-34, 74-84 and 84-92.6\%, respectively, as shown in Table 3. Ngamlerdpokin et al. 2011 observed that the significant removal of raw biodiesel (containing FFA and FAME) in the presence of a strong proton donor. It may be speculated that $\mathrm{H}^{+}$from $\mathrm{H}_{2} \mathrm{SO}_{4}$ would quickly neutralize any residual alkali catalyst in the biodiesel wastewater and substitute the $\mathrm{Na}$ atom in the soap molecule, arising from the reaction between triglyceride and base catalyst $(\mathrm{NaOH})$ in the presence of water in the initial feedstock, or by esterification of FFA in the feedstock with alcohol, leading to the formation of uncharged FFA. In addition, it can also substitute the $\mathrm{H}_{2} \mathrm{O}$ molecule containing biodiesel leading to the formation of the free FAME (Jaruwat et al. 2010). A significantly higher removal efficiency of all pollutants was observed under strong acidic conditions (at $\mathrm{pH}$ of 2.5 especially 2). This is attributed to the fact that large amount of raw biodiesel was

Table 3 Mean value of organic pollutants after pretreatment with $\mathrm{H}_{2} \mathrm{SO}_{4}$

\begin{tabular}{lllllll}
\hline $\mathrm{pH}$ & $\begin{array}{l}\text { COD value after } \\
\text { treatment }(\mathrm{mg} / \mathrm{L})\end{array}$ & $\begin{array}{l}\text { Removal }(\%) \\
\text { of COD }\end{array}$ & $\begin{array}{l}\text { O\&G value after } \\
\text { treatment }(\mathrm{mg} / \mathrm{L})\end{array}$ & $\begin{array}{l}\text { Removal }(\%) \\
\text { of O\&G }\end{array}$ & $\begin{array}{l}\text { BOD value after } \\
\text { treatment }(\mathrm{mg} / \mathrm{L})\end{array}$ & $\begin{array}{l}\text { Removal }(\%) \\
\text { of BOD }\end{array}$ \\
\hline 2 & $10,273( \pm 74)$ & 84.1 & $1,521( \pm 9)$ & 92.6 & $22,597( \pm 62)$ & 33.5 \\
2.5 & $10,618( \pm 67)$ & 83.6 & $2,411( \pm 11)$ & 88.2 & $23,605( \pm 67)$ & 30.6 \\
3 & $16,742( \pm 63)$ & 74.1 & $3,247( \pm 14)$ & 84.2 & $24,702( \pm 63)$ & 27.3 \\
\hline
\end{tabular}


separated under these acidic conditions, leading to lower amount of organic substances, particularly oil and grease, in the residual wastewater.

\section{Effect of HRT on biomass concentration and TMP}

The reactor was run at HRTs of 15, 12, 9 and $6 \mathrm{~h}$, and at each HRT, organic loading rate (OLR) was varied from 1 to 2 and $3 \mathrm{~g} / \mathrm{L}$ day. When the reactor was operated at an HRT of $15 \mathrm{~h}$, the MLSS concentration was reported as 2.5-5.8 $\mathrm{mg} / \mathrm{L}$, as shown in Table 4, an increase in MLSS concentration at HRT of $15 \mathrm{~h}$ occurred due to varying the OLR; similar trend was observed for HRT of 12, 9 and $6 \mathrm{~h}$ as described in Table 4. However, a significant increase in MLSS concentration was observed while decreasing the HRT from $15 \mathrm{~h}$ to 12,9 and $6 \mathrm{~h}$ because shorter HRT provides more nutrients to the biomass and leads to a higher biological growth and so a higher MLSS (Dufresne et al. 1998). According to Nagaoka et al. (1998), MLSS is also directly influenced by organic loading rate (OLR); therefore, when OLR was varied from 1 to 2 and $3 \mathrm{~g} / \mathrm{L}$ day on each HRT, an increase in MLSS concentration was also reported, as shown in Fig. 2. Due to an increase in MLSS concentration, at lower HRTs, membrane fouled more quickly as compared to that in higher HRTs because membrane exposed with more concentrated culture and higher non-Newtonian viscosity at lower HRT, which caused the membrane fouling faster (Table 5). Chang and Kim (2005) observed that the increase in MLSS concentration seems to have a mostly negative impact (higher TMP or lower flux) on the MBR hydraulic performance.
However, some authors have reported positive impact (Brookes and Jefferson 2006), and some observed insignificant impact (Hong et al. 2002; Lesjean et al. 2005).

MLVSS/MLSS ratio was also analyzed to find out the effect of organic content on membrane fouling. MLVSS/ MLSS increased when HRT was decreased due to increase in MLSS concentration. Mean values of MLVSS/MLSS ratio at HRTs of 15, 12, 9 and $6 \mathrm{~h}$ are reported in Table 4. Jefferson and Brookes (2004) observed that there is a lack of a clear correlation between MLSS concentration and any other foulant characteristics and indicated that the MLSS concentration (alone) is a poor indicator of biomass fouling propensity. Therefore, in the present work, the influence of HRT on membrane fouling is analyzed, and the relationship between HRT and biomass characteristics, including soluble microbial product (SMP), particle size distribution (PSD) and dissolved oxygen (DO) concentration, is studied systematically to specify how HRT affects membrane fouling.

\section{COD and O\&G removal efficiency}

COD and O\&G removal efficiency was also examined at different HRTs, and an increase in COD removal efficiency was observed by varying the operating time for each HRT from 10 to 15 days. At 10 days of operation, COD removal efficiency was reported as 97-97.9, 94.7-96.4, 92.9-93.3 and $90.8-91.2 \%$ with the HRTs of $15,12,9$ and $6 \mathrm{~h}$, respectively, as shown in Table 4 , while at 15 days of operation, COD removal efficiency was reported as 97.7-98.6, 95.8-97, 94-95.2 and 91.7-92.8\% at HRTs of $15,12,9$ and $6 \mathrm{~h}$, respectively (Table 4). When operating

Table 4 Mean values of monitoring parameters of MBR at different HRTs

\begin{tabular}{|c|c|c|c|c|c|c|c|c|}
\hline \multirow[t]{3}{*}{ Parameters } & \multicolumn{8}{|c|}{ HRT (h) } \\
\hline & \multicolumn{2}{|l|}{15} & \multicolumn{2}{|l|}{12} & \multicolumn{2}{|l|}{9} & \multicolumn{2}{|l|}{6} \\
\hline & Min. & Max. & Min. & Max. & Min. & Max. & Min. & Max. \\
\hline Removal (\%) of COD (after 10 days) & 97 & 97.9 & 94.7 & 96.4 & 92.9 & 93.3 & 90.8 & 91.2 \\
\hline Removal (\%) of COD (after 15 days) & 97.7 & 98.6 & 95.8 & 97 & 94 & 95.2 & 91.7 & 92.8 \\
\hline Removal (\%) of O\&G (after 10 days) & 97.5 & 98.4 & 97.1 & 97.4 & 96.1 & 96.4 & 95.2 & 95.3 \\
\hline Removal (\%) of O\&G (after 15 days) & 97.9 & 98.7 & 97.2 & 97.9 & 96.6 & 97 & 95.5 & 96 \\
\hline MLSS (g/L) & 2.5 & 5.8 & 2.6 & 6.5 & 3.2 & 12.2 & 6.1 & 16.2 \\
\hline MLVSS/MLSS & 0.52 & 0.61 & 0.57 & 0.67 & 0.57 & 0.71 & 0.56 & 0.82 \\
\hline $\mathrm{DO}(\mathrm{mg} / \mathrm{L})$ & 2.2 & 3.2 & 1.9 & 3.3 & 1.2 & 2.5 & 1.1 & 2.6 \\
\hline Particle size $(\mu \mathrm{m})$ & 12.5 & 29.6 & 15.2 & 36.2 & 14.6 & 49.8 & 27.9 & 62.7 \\
\hline Protein (mg/L) & 8 & 26 & 14 & 38 & 21 & 50 & 20 & 60 \\
\hline Polysaccharide (mg/L) & 7 & 25 & 12 & 37 & 20 & 49 & 19 & 59 \\
\hline Membrane clogging (days) & 12 & 17 & 6 & 12 & 5 & 8 & 3 & 6 \\
\hline
\end{tabular}


Fig. 2 Effect of HRTs on biomass concentration in MBR

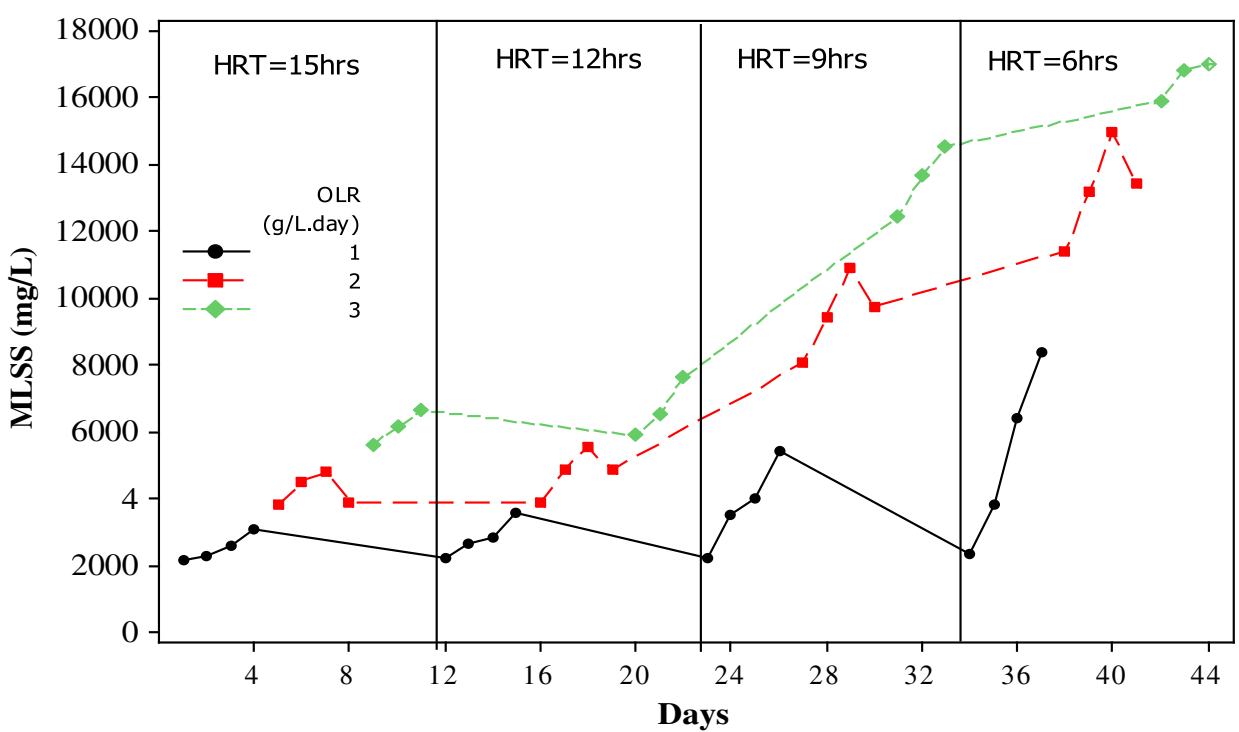

Table 5 Membrane clogging with respect to OLRs at different HRTs \begin{tabular}{llll}
\hline HRT (h) Flux ( $\left./ \mathrm{m}^{2} \mathrm{~h}\right)$ & TMP (KPa) & Membrane clogging (days)
\end{tabular}

\begin{tabular}{llrrrr} 
& & 1 & 2 & 3 \\
\hline 15 & 12 & $\leq 50$ & 17 & 15 & 12 \\
12 & 14 & $\leq 50$ & 12 & 9 & 6 \\
9 & 19 & $\leq 50$ & 8 & 7 & 5 \\
6 & 29 & $\leq 50$ & 6 & 4 & 3 \\
\hline
\end{tabular}

* 1,2 and 3 represents the OLR (g/L day)

time was increased from 10 to 15 days, the efficiency of MBR increased because at longer operating times, organic pollutants degrade more efficiently when compared to the shorter operating time. It was also observed that COD removal efficiency decreased due to an increase in OLR because higher OLR induced more nutrients to biomass, which increased the MLSS concentration in MBR and decreased biomass activity; similar trend was observed by Meng et al. 2007 that an increase in MLSS concentration and sludge viscosity would lead to an increase in oxygen and substrate diffusion limitation in the sludge suspension, so the activities of biomass decreased.

O\&G removal efficiency followed the same pattern as COD removal efficiency, which was reported as 97.5-98.4, 97.1-97.4, 96.1-96.4 and 95.2-95.3\% at HRTs 15, 12, 9 and $6 \mathrm{~h}$, respectively, with the corresponding operating time of 10 days, as described in Table 4; however, at an operating time of 15 days, O\&G removal efficiency was reported as 97.9-98.7, 97.2-97.9, 96.6-97 and 95.5-96\% at HRTs of 15, 12, 9 and $6 \mathrm{~h}$, respectively (Table 4).

Effect of DO concentration on TMP

The impact of HRT on DO concentration was analyzed, and it was found that decrease in HRT had a greater impact on DO concentration. When the reactor was run at an HRT of $15 \mathrm{~h}$, the DO concentration was reported as $3.2-2.2 \mathrm{mg} / \mathrm{L}$, as shown in Table 4. Decrease in DO concentration was observed due to an increase in OLR at an HRT of $15 \mathrm{~h}$ because at higher OLR, MLSS concentration increased, which utilized more oxygen for biodegradation. Similar trends were observed at HRTs 12, 9 and $6 \mathrm{~h}$, but it was revealed that DO concentration decreased tremendously when HRT was decreased from 15 to 12,9 and $6 \mathrm{~h}$. Meng et al. 2007 explained that this might be an impeded transfer rate of both substrate and oxygen due to an increase in the sludge viscosity and MLSS concentration at short HRT or high OLR. Therefore, it was concluded that shorter HRT induced more MLSS concentration in bioreactor, which caused the higher utilization of DO concentration in bioreactor. DO concentration is also directly influenced by organic loading rate (OLR); therefore, when OLR was varied from 1 to 2 and $3 \mathrm{~g} / \mathrm{L}$ day on each HRT, decrease in DO concentration was also reported, as shown in Fig. 3. Due to decrease in DO concentration, at lower HRTs, membrane fouled more quickly when compared to higher HRT 


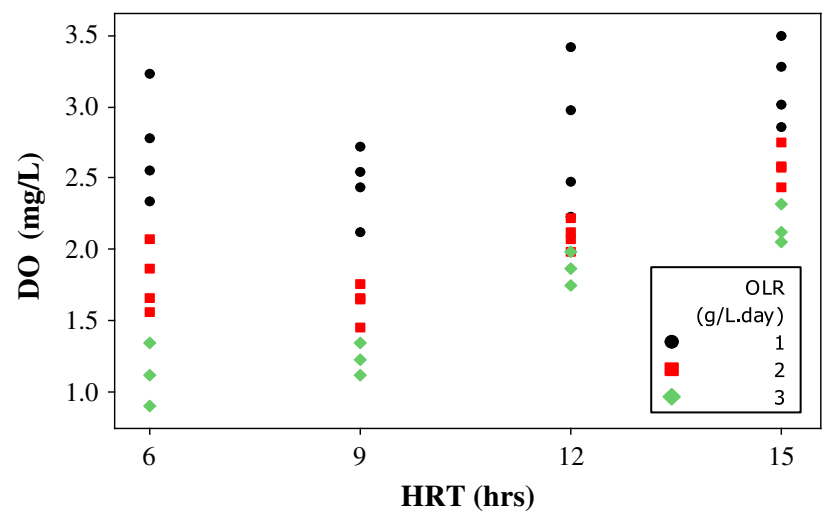

Fig. 3 Evaluation of DO concentration at different HRTs

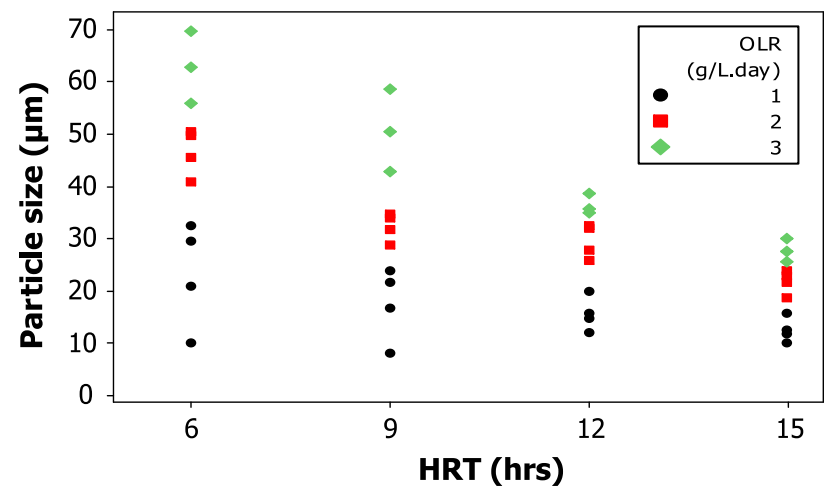

Fig. 4 Particle size distributions in MBR

(Table 5). Huang and Ong (2010) reported that when HRT decreased, membrane fouling occurred faster at constant membrane surface area.

\section{Particle size distribution}

Particle size distributions of flocs were also analyzed by varying the HRTs. It was observed that particle size increased while HRT decreased. When the reactor was run at an HRT of $15 \mathrm{~h}$, an increase in particle size was observed as 12.52-29.59 $\mu \mathrm{m}$, as shown in Table 4; an increase in particle size was observed due to an increase in MLSS concentration at higher OLR, which caused severe membrane fouling due to overgrowth of filamentous bacteria as explained by Wilen and Balmer 1999, because when filamentous microorganisms started to grow, the sludge flocs became more irregularly shaped and porous. Thus, it was concluded that the overgrowth of filamentous bacteria and the low shear stress were the main reasons that led to irregular particle shape at lower HRT, which caused severe membrane fouling. Similar trends for particle size growth were obtained for HRTs of 12,9 and $6 \mathrm{~h}$, as mentioned in Table 4.

Figure 4 illustrates the impact of HRT on particle size, and it was revealed that at HRTs of 15, 12, 9 and $6 \mathrm{~h}$, membrane operation was terminated around 12-17, 6-12, 5-8 and 3-6 days, respectively, as shown in Table 5, because shorter HRTs led to decrease in DO concentration continuously, which caused severe membrane fouling.

Evolution of SMP in sludge suspension

Although the influence of dissolved matter has been studied for a decade, the concept of SMP fouling in the MBR is relatively new as no report on SMP levels existed for MBRs prior to 2001 (Chang et al. 2002). In order to reveal the feasibility and relevance of liquid-phase analyses on MBR filterability, SMP analysis was carried out. In this research, SMP was categorized as $\mathrm{SMP}_{\mathrm{p}}$ (protein) and $\mathrm{SMP}_{\mathrm{c}}$ (polysaccharide) to evaluate their impact on membrane fouling. When the reactor was run at an HRT of $15 \mathrm{~h}$, mean $\mathrm{SMP}_{\mathrm{p}}$ value was reported as 8-26 mg/L, while $\mathrm{SMP}_{\mathrm{c}}$ concentration was reported as $7-25 \mathrm{mg} / \mathrm{L}$ with the corresponding OLRs of 1,2 and $3 \mathrm{~g} / \mathrm{L}$ day (Table 4). Increase in $\mathrm{SMP}_{\mathrm{p}}$ and $\mathrm{SMP}_{\mathrm{c}}$ concentrations was resulted due to increase in OLRs at an HRT of $15 \mathrm{~h}$. It was observed that higher OLRs induced more nutrients in bioreactor, which led to an increase in MLSS concentration. Similar trends were also observed for HRTs 12, 9 and $6 \mathrm{~h}$.

Table 5 shows that membrane operation was terminated around $12-17,6-12,5-8$ and 3-6 days with the corresponding HRT of 15, 12, 9 and $6 \mathrm{~h}$, respectively. Hence, it was concluded that an increase in SMP production led to increase membrane fouling. Rosenberger et al. 2005 explained that during filtration, SMP adsorbs on the membrane surface, blocks membrane pores and/or forms a gel structure on the membrane surface where they provide a possible nutrient source for biofilm formation and a hydraulic resistance to permeate flow.

\section{Conclusion}

In this research, MBR was proposed an alternative technology for wastewater treatment of biodiesel plants. The 
whole research was divided into two parts: pretreatment of biodiesel wastewater and MBR treatment. In pretreatment step, $\mathrm{H}_{2} \mathrm{SO}_{4}$ of $\mathrm{pH} 2,2.5$ and 3 was used to treat the wastewater of biodiesel plants. Significant reduction in organic pollutants was obtained at $\mathrm{pH} 2.5$ due to strong protonation effect of $\mathrm{H}_{2} \mathrm{SO}_{4}$. $\mathrm{COD}$ and $\mathrm{O} \& \mathrm{G}$ were found to be 74-84 and 84-92.6\%, respectively. However, a slight increase in removal (\%) of organic pollutants was observed at a lower $\mathrm{pH}$ of 2 . To improve the treatment efficiency of the process, MBR was incorporated as a secondary treatment. Fouling mechanism in MBR was investigated by varying the HRT and OLR. Following conclusions were reported from the results obtained during the experiments. COD and O\&G removal efficiency in the bioreactor slightly decreased with decreasing HRT, while the overall efficiency of COD and O\&G remained in the range of 92.8-98.6 and $95.7-98.7 \mathrm{mg} / \mathrm{L}$, respectively, because shorter HRT induced more MLSS concentration in reactor, which led to decrease in the biomass activity as higher MLSS concentration would lead to an increase in oxygen and substrate diffusion limitation in the sludge suspension. HRT was correlated with dissolved oxygen (DO), particle size distribution (PDS) and soluble microbial product (SMP) in order to investigate their impact on membrane fouling mechanism. TMP about $50 \mathrm{kPa}$ achieved within 4 days at an HRT of $6 \mathrm{~h}$. This can be explained by low back-transport of velocity of smaller particles at low DO concentration because at lower DO concentration, particles had poor settling properties and higher turbidities of the effluent than at higher DO concentration, which could be the reason for severe membrane fouling . SMP $\mathrm{p}_{\mathrm{p}}$ and $\mathrm{SMP}_{\mathrm{c}}$ were increased simultaneously with decrease in HRT. However, $\mathrm{SMP}_{\mathrm{p}}$ was found slightly higher than $\mathrm{SMP}_{\mathrm{c}}$ in our research. Therefore, it was concluded that both played active role in membrane fouling in contradiction to previous research, in which $\mathrm{SMP}_{\mathrm{c}}$ was major fouling indicator.

Acknowledgments The authors gratefully acknowledge the great support from the Graduate School of Prince of Songkhla University and DOE (Discipline of Excellent Chemical Engineering).

\section{Abbreviations}

$\begin{array}{ll}\text { COD } & \text { Chemical oxygen demand }(\mathrm{mg} / \mathrm{L}) \\ \text { BOD } & \text { Biological oxygen demand }(\mathrm{mg} / \mathrm{L}) \\ \text { O\&G } & \text { Oil and grease }(\mathrm{mg} / \mathrm{L}) \\ \text { HRT } & \text { Hydraulic retention time }(\mathrm{h}) \\ \text { MLSS } & \text { Mixed liquid suspended solids }(\mathrm{mg} / \mathrm{L}) \\ \text { MLVSS } & \text { Mixed liquid volatile suspended solids } \\ & (\mathrm{mg} / \mathrm{L}) \\ \text { SMP } & \text { Soluble microbial products }(\mathrm{mg} / \mathrm{L})\end{array}$

SMPp Soluble microbial product containing protein $(\mathrm{mg} / \mathrm{L})$

SMPc Soluble microbial product containing polysaccharide $(\mathrm{mg} / \mathrm{L})$

DO Dissolved oxygen $(\mathrm{mg} / \mathrm{L})$

PSD Particle size distribution $(\mu \mathrm{m})$

TMP Transmembrane pressure (KPa)

FFA Free fatty acids $(\mathrm{mL} / \mathrm{L})$

FAME Fatty acid methyl esters $(\mathrm{mL} / \mathrm{L})$

OLR Organic loading rate $(\mathrm{g} / \mathrm{L}$ day)

SRT Solid retention time (days)

\section{Appendix 1: COD input calculations for MBR}

1. Calculation of COD input

$\mathrm{HRT}=\frac{V}{J \times A}$

Or

Table 6 Values of operation parameters used in calculations

\begin{tabular}{lll}
\hline Parameters & Unit & Values \\
\hline Filtration area (A) & $\mathrm{m}^{2}$ & 0.23 \\
Volume of reactor (V) & $\mathrm{L}$ & 50 \\
Hydraulic retention time (HRT) & $\mathrm{h}$ & $15,12,9,6$ \\
Volumetric organic loading rate (VOLR) & $\mathrm{g} / \mathrm{L}$ day & $1,2,3$ \\
\hline
\end{tabular}

Table 7 COD input calculations for MBR

\begin{tabular}{lllllll}
\hline $\begin{array}{l}\text { OLR } \\
(\mathrm{g} /\end{array}$ & $\begin{array}{l}\text { Volume } \\
\text { L day }) \\
\text { reactor } \\
(\mathrm{L})\end{array}$ & $\begin{array}{l}\text { HRT } \\
(\mathrm{h})\end{array}$ & $\begin{array}{l}\text { Flux } \\
\text { rate } \\
(\mathrm{L} / \\
\left.\mathrm{m}^{2} \mathrm{~h}\right)\end{array}$ & $\begin{array}{l}\text { Permeate } \\
\text { flow rate } \\
(\mathrm{L} / \mathrm{h})\end{array}$ & $\begin{array}{l}\text { Permeate } \\
\text { flow rate } \\
(\mathrm{L} / \text { day })\end{array}$ & $\begin{array}{l}\text { COD } \\
\text { input } \\
(\mathrm{mg} /\end{array}$ \\
\hline 1 & 50 & 6 & 36 & 8 & 200 & 250 \\
1 & 50 & 9 & 24 & 6 & 133 & 375 \\
1 & 50 & 12 & 18 & 4 & 100 & 500 \\
1 & 50 & 15 & 14 & 3 & 80 & 625 \\
2 & 50 & 6 & 36 & 8 & 200 & 500 \\
2 & 50 & 9 & 24 & 6 & 133 & 750 \\
2 & 50 & 12 & 18 & 4 & 100 & 1,000 \\
2 & 50 & 15 & 14 & 3 & 80 & 1,250 \\
3 & 50 & 6 & 36 & 8 & 200 & 750 \\
3 & 50 & 9 & 24 & 6 & 133 & 1,125 \\
3 & 50 & 12 & 18 & 4 & 100 & 1,500 \\
3 & 50 & 15 & 14 & 3 & 80 & 1,875 \\
\hline
\end{tabular}


$J=\frac{V}{\operatorname{HRT} \times A}$,

where HRT is hydraulic retention time (h), $V$ is volume of reactor $(L), A$ is filtration area $\left(\mathrm{m}^{2}\right)$, and $J$ is permeate flux $\left(\mathrm{L} / \mathrm{m}^{2} \mathrm{~h}\right)$

$\operatorname{VOLR}=\frac{S 0 \times Q}{V}$

Or

$S_{0}=\frac{\operatorname{VOLR} \times V}{Q}$,

where VOLR is volumetric organic loading rate ( $\mathrm{g} / \mathrm{L}$ day), $V$ is volume of reactor $(L), Q$ is permeate flow rate ( $L /$ day), and $S_{0}$ is COD input $(\mathrm{mg} / \mathrm{L})($ Tables 6,7$)$

\section{References}

APHA (1995) Standard methods for the examination of water and wastewater, 19th edn. American Public Health Association, Baltimore

Berrios M, Skelton L (2008) Comparison of purification methods of biodiesel. Chem Eng J 144:459-465

Bolzonella D, Pavan P, Battistoni P, Cecchi F (2006) Anaerobic codigestion of sludge with other organic wastes and phosphorus reclamation in wastewater treatment plants for biological nutrients removal. Water Sci Technol 53:177-186

Brookes A, Jefferson B, Guglielmi G, Judd J (2006) Sustainable flux fouling in a membrane bioreactor: impact of flux and MLSS. Sep Sci Technol 41:1279-1291

Calvo L, Leclerc J, Tanguy G, Cames M, Patemotte G, Valentin G, Rostan A, Lapicque F (2003) An electrocoagulation unit for the purification of soluble oil wastes of high COD. Environ Prog 22:57-65

Canakci M, Gerpen V (2001) Biodiesel production from oils and fats with high free fatty acids. Trans ASAE 44:1429-1436

Chang S, Kim N (2005) Wastewater treatment using membrane filtration-effect of biosolids concentration on cake resistance. Process Biochem 40:1307-1314

Chang S, Le Clech P, Jefferson B, Judd S (2002) Membrane fouling in membrane bioreactors for wastewater treatment. J Environ Eng ASCE 128:1018-1029

Chavalparit O, Meanseta P (2006) Treatment of agro-industrial wastewater by means of electro-coagulation: crude palm oil mill in Thailand. In: Proceedings of the 12th Thailand-Korea Conference Environmental Engineering, Korea Advanced Institute of Science and Technology (KAIST), Soul, Korea, 21-25

Chavalparit O, Ongwandee M (2009) Optimizing electrocoagulation process for the treatment of biodiesel wastewater using response surface methodology (RSM). J Environ Sci 21:1491-1496

Dufresne R, Lavallee C, Lebrun E, Lo N (1998) Comparison of performance between membrane bioreactor and activated sludge system for the treatment of pulping process wastewaters. Tappi J 81:131-135

Emamjomeh M, Sivakumar M (2009) Review of pollutants removed by electrocoagulation and electrocoagulation/flotation processes. J Environ Manage 90:1663-1667
Feng C, Sugiura N, Maekawa T (2004) Performance of two new electrochemical treatment system for wastewaters. J Environ Sci Health 39:2533-2543

Frost and Sullivan (2003) European bioreactor market. Report B208

Frost and Sullivan (2010) Growing opportunities for membrane systems in Indian water and wastewater treatment market, Report

Hong P, Bae H, Tak M, Hong A (2002) Randall, Fouling control in activated sludge submerged hollow fiber membrane bioreactors. Desalination 143:219-228

Huang Z, Ong L, Ng Y (2010) Submerged anaerobic membrane bioreactor for low-strength wastewater treatment: effect of HRT and SRT on treatment performance and membrane fouling. J Water Res 45:1543-1554

IPPC-Reference Document on Best Available Techniques in Common Waste Water and Waste Gas Treatment/Management Systems in the Chemical Sector, Feb (2003). http://eippcb.jrc.es

Jaruwat P, Kongiao S, Hunsom M (2010) Management of biodiesel wastewater by the combined processes of chemical recovery and electrochemical treatment. Energy Conver Manage 51:531-537

Jefferson B, Brookes A, Le-Clech P, Judd J (2004) Methods for understanding organic fouling in MBRs. Water Sci Technol 49:237-244

Kato S, Yoshimura H, Hirose K, Amornkitbamurung M, Sakka M, Sugahara I (2005) Application of microbial consortium system to wastewater from biodiesel fuel generator. IEA-Waterqual, Singapore, CD-ROM

Kimura J (1991) Japan's aqua renaissance'90 project. Water Sci Technol 23:1573-1582

Lesjean B, Rosenberge S, Laabs C, Jekel M, Gnirss R, Amy G (2005) Correlation between membrane fouling and soluble/colloidal organic substances in membrane bioreactors for municipal wastewater treatment. Water Sci Technol 51:1-8

Marchetti M, Miguel U, Errazu F (2007) Possible methods for biodiesel production. Renew Sustain Energy Rev 11:1300-1311

Meng F, Shi B, Yang F, Zhang H (2007) Effect of hydraulic retention time on membrane fouling and biomass characteristics in submerged membrane bioreactors. Bioprocess Biosyst Eng 30:359-367

Nagaoka H, Yamanishi S, Miya A (1998) Modeling of biofouling by extracellular polymers in a membrane separation activated sludge. Water Sci Technol 38:497-504

Ngamlerdpokin K, Kumjadpai S, Chatanon P, Tungmanee U, Chuenchuanchom S, Jaruwat P, Lertsathitphongs P, Hunsom M (2011) Remediation of biodiesel wastewater by chemical and electro-coagulation. J Environ Manage 92:2454-2460

Nishiro N, Nakashimada Y (2007) Recent development of anaerobic digestion processes for energy recovery from wastes. J Biosci Bioeng 103:105-112

Raunkjaer K, Hvitved T, Nielsen H (1994) Measurement of pools of protein, carbohydrate and lipid in domestic wastewater. J Water Res 28:251-262

Rosenberger S, Evenblij H, Te S, Wintgens T, Laabs C (2005) The importance of liquid phase analyses to understand fouling in membrane assisted activated sludge processes-six case studies of different European research groups. J Membr Sci 263:113-126

Siles J, Gutiérrez M, Martin M, Martin A (2011) Physical-chemical and biomethanization treatments of wastewater from biodiesel manufacturing. Bioresour Technol 102:6348-6351

Suehara K, Kawamoto Y, Fujii E, Kohda J, Nakano Y, Yano T (2005) Biological treatment of wastewater discharged from biodiesel fuel production plant with alkali-catalyzed trans-esterification. J Biosci Bioeng 100:437-442 
Tri P (2002) Oily wastewater treatment by membrane bioreactor process coupled with biological activated carbon process, Thesis: AIT. Bangkok, Thailand
Wilen M, Balmer P (1999) The effect of dissolved oxygen concentration on the structure, size and size distribution of activated sludge flocs. Water Res 33:391-400 